\title{
EKSISTENSI PRAKTIK JUAL GADAI (ADOL SENDE) PADA MASYARAKAT DUSUN PENTONG KELURAHAN SELOREJO KECAMATAN PUNDHONG KABUPATEN BANTUL
}

\author{
Nur Putri Hidayah, Inda Rahadiyan \\ Fakultas Hukum Universitas Muhammadiyah Malang \\ Fakultas Hukum Universitas Islam Indonesia \\ Jalan Raya Tlogomas No. 246 Malang \\ Jalan Kaliurang km. 14,5 Yogyakarta. \\ Email: nurputri@umm.ac.id, indarahadiyan@yahoo.com
}

\begin{abstract}
Adol sende is a form of assurance that currently exists in rural and indigenous communities. Adol sende is implemented as an effort to fulfill people's life needs. But in practice, there is an extortion element in the implementation of adol sende because the object of guarantee is too long controlled by the creditor (controlled and used). This causes the debtor does not get the economic rights of the land which is used as the object of adol sende. In Article 7 of Act Number 56 Prp.1960 the government provides a limitation of the timing of adol sende implementation to overcome the extortion in farming practices. The purpose of this research is to know how to implement pawn transaction (adol sende) and constraints faced by people who live in Pentong Hamlet, Selorejo Subdistrict, Pundhong District, Bantul Regency in connection with the implementation of Article 7 of Law Number 56 Prp 1960. The research method is empirical sociology, research location is Pentong Hamlet, Selorejo Village, Pundhong District, Bantul Regency. The result of the research is the implementation of adol sende by the people of Pentong Hamlet, in relation to the implementation of Article 7 of Law Number 56 Prp 1960, there was no harmony. The Pentong community remains in their living law, where the implementation of adol sende is unlimited. The obstacles in the implementation of adol sende consists of 2 things, internal constraints because of ignorance of the community itself over the time limits set by the government. While external constraints exist in the absence of education in the form of socialization of the government against the provisions of Article 7 of Law Number 56 Prp 1960.
\end{abstract}

Keywords: Adol Sende, Mortgage, Pentong Hamlet

\begin{abstract}
Abstrak
Adol sende adalah bentuk jaminan yang saat ini masih eksis di masyarakat pedesaan maupun masyarakat adat. Adol sende dilakukan sebagai upaya memenuhi kebutuhan hidup masyarakat. Namun pada praktiknya, terdapat unsur pemerasan dalam pelaksanaan adol sende karena objek jaminan terlalu lama dikuasai oleh kreditur (dikuasai dan dipergunakan). Hal ini menyebabkan debitur tidak mendapatkan hak ekonomis dari tanah yang dijadikan objek adol sende. Pada Pasal 7 Undang-Undang Nomor 56 Prp.1960 pemerintah memberikan Batasan waktu pelaksanaan adol sende untuk mengatasi terjadinya pemerasan dalam praktik jual gadai tanah pertanian. Penelitian ini bertujuan untuk mengeatahui bagaimana pelaksanaan transaksi jual gadai (adol sende) dan kendala yang dihadapi oleh masyarakat yang bertempat tinggal di Dusun Pentong, Kelurahan Selorejo, Kecamatan Pundhong, Kabupaten Bantul dalam kaitannya dengan pemberlakuan Pasal 7 Undang-Undang Nomor 56 Prp 1960. Metode
\end{abstract}


penelitian adalah sosiologis empiris yang berlokasi pada Dusun Pentong, Kelurahan Selorejo, Kecamatan Pundhong, Kabupaten Bantul. Hasil penelitian menunjukan bahwa pelaksanaan adol sende oleh masyarakat Dusun Pentong, dalam kaitannya dengan pemberlakuan Pasal 7 Undang-Undang Nomor 56 Prp 1960 ternyata tidak terjadi keharmonisan. Masyarakat dusun Pentong tetap pada living law mereka, dimana pelaksanaan adol sende ini tanpa batasan waktu. Adapun kendala dalam pelaksanaan adol sende terdiri dari 2 hal, kendala internal karena ketidak tahuan masyarakat sendiri atas batasan waktu yang telah ditetapkan pemerintah. Sedangkan kendala eksternal ada pada belum adanya edukasi berupa sosialisasi dari pemerintah terhadap ketentuan Pasal 7 Undang-Undang Nomor 56 Prp 1960.

\section{Kata Kunci: Adol Sende, Gadai Tanah, Dusun Pentong}

\section{A. PENDAHULUAN}

Keanekaragaman budaya yang dimiliki oleh bangsa Indonesia merupakan aset dalam rangka membangun konsepsi hukum yang terus berkembang mengikuti perkembangan masyarakat dan menjadikan hukum sebagai sarana pembaruan masyarakat dengan memfungsikannya sebagai pengatur kehidupan bermasyarakat. ${ }^{1}$ Dengan demikian dapat dipahami pula bahwa dinamisasi peraturan hukum harus senantiasa berkembang seiring dengan dinamisasi kehidupan masyarakat tak terkecuali masyarakat hukum adat.

Dinamisasi kehidupan masyarakat adat terutama ditandai dengan berbagai transaksi khususnya di bidang ekonomi yang senatiasa berlangsung dan mengalami perkembangan. Pelaksanaan berbagai transaksi ini dapat dipandang sebagai salah satu upaya pemenuhan kebutuhan hidup bagi masyarakat. Salah satu bentuk transaksi yang hingga saat ini masih hidup dan dilaksanakan adalah transaksi mengenai jual gadai tanah yang dalam masyarakat Jawa dikenal dengan istilah adol sende.

Secara umum jual gadai ${ }^{2}$ merupakan suatu transaksi yang dilakukan berdasarkan adat istiadat dan kebiasaan oleh masyarakat dalam bentuk lisan berdasarkan kata sepakat, kepercayaan serta itikad baik melalui penyerahan tanah dari salah satu pihak kepada pihak lain dengan maksud untuk dikuasai dalam jangka waktu tertentu dengan diikuti pembayaran sejumlah uang tertentu secara tunai serta adanya hak bagi penerima gadai untuk menebus kembali tanah yang telah dijual gadaikan kepada pemberi gadai. ${ }^{3}$ Dalam hal ini keberadaan hak unuk menebus kembai menjadi salah satu karakteristik dari transaksi jual gadai (adol sende).

Pelaksanaan transaksi jual gadai (adol sende) ini pada satu sisi merupakan salah satu upaya bagi masyarakat dalam rangka memenuhi kebutuhan hidupnya. Seorang anggota masyarakat yang terdesak oleh kebutuhan ekonomi dapat melakukan transaksi jual gadai (adol sende)

\footnotetext{
${ }^{1}$ Apabila ditinjau bedasarkan kebutuhan ekonomi, jual gadai ini merupakan suatu upaya pemenuhan kebutuhan hidup dalam masyarakat yang dilakukan melalui suatu bentuk transaksi sederhana dan kental dengan nuansa kekeluragaan. Pelaksanaan transaksi ini meujukan salah satu gambaran bahwa hukum negara dalam bidang ini belum terjangkau dan dikenal oleh segenap lapisan masyarakat Indonesia.

${ }^{2}$ Ukilah Supriyatin, Jaminan Kepastian Hukum Terhadap Perjanjian Gadai Tanah Menurut Hukum Adat, http://jurnal.pdii.lipi.go.id/admin/jurnal/13101118_2086-8111.pdf

${ }^{3}$ Ibid
} 
dengan seorang anggota masyarakat yang lain sebagai upaya dalam rangka mengatasi kebutuhannya akan uang tunai. Namun demikian pada tataran pelaksanaannya timbul berbagai permasalahan hukum berkaitan dengan transaksi jual gadai atau adol sende ini. Permasalahan hukum yang kemudian muncul terutama mengenai terdapatnya dualisme pengaturan hukum atas transaksi jual gadai yang semula tunduk pada ketentuan hukum adat kemudian menjadi suatu transaksi yang diatur dengan peraturan perundang-undangan oleh pemerintah.

Anggapan pemerintah mengenai adanya unsur pemerasan dalam transaksi jual gadai (adol sende) kemudian mendorong dikeluarkannya peraturan perundang-undangan mengenai transaksi tersebut. Munculnya anggapan demikian dapat dipahami mengingat dalam hukum adat tidak diatur secara tegas mengenai batas jangka waktu maksimal bagi pelaksanaan jual gadai. Ketiadaan ketentuan yang tegas mengenai batas jangka waktu maksimal bagi pelaksanaan jual gadai memungkinkan timbulnya pemerasan secara ekonomis yang dilakukan oleh pihak penerima gadai kepada pihak penggadai. Dalam praktik, sebagian transaksi gadai tanah di Pulau Jawa (adol sende) terlihat merugikan pihak penggadai (pemilik tanah). Karena terdesak akan kebutuhan uang, petani kemudian menggadaikan tanah miliknya yang dalam beberapa kondisi tertentu hal demikian justru mengakibatkan pihak penggadai terjerat oleh lintah darat. ${ }^{4}$ Namun demikian pelaksanaan jual gadai ini tak jarang juga menimbulkan kerugian bagi penerima gadai yang beritikad baik.

Penetapan Pasal 7 Undang-Undang Nomor 56 Prp.1960 merupakan upaya yang dilakukan oleh pemerintah dalam rangka mengatasi kemunculan unsur pemerasan dalam praktik jual gadai tanah pertanian. Pasal 7 undang-undang ini pada intinya mewajibkan bagi pihak penerima gadai yang telah melakukan penguasaan atas tanah gadai selama tujuh tahun atau lebih untuk mengembalikan penguasaan atas tanah kepada pihak penggadai. ${ }^{5}$ Pengaturan demikian dimaksudkan demi terwujudnya perlindungan hukum khususnya bagi pihak penggadai yang pada umumnya memiliki kedudukan lebih lemah di bidang ekonomi apabila dihadapkan dengan pihak penerima gadai.

Penelitian yang mengenai jual gadai telah dilakukan oleh beberapa peneliti sebelumnya. Aliasman dalam tesisnya di tahun 2005dengan judul Pelaksanaan Gadai Tanah Dalam Masyarakat Hukum Adat Minangkabau Di Nagari Campago Kabupaten Padang Pariaman Setelah Berlakunya Pasal 7 Undang-Undang Nomor 56 Prp 1960, membahas mengenai permasalahan pelaksanaan jual gadai tanah di Nagari Campago, Kabupaten Padang Pariaman pasca berlakunya Pasal 7 Undang-Undang Nomor 56 Prp 1960. Selain itu, peneliti lain Suhardi meneliti Pengaruh Peraturan Gadai Tanah Pertanian (Pasal 7 Undang-Undang Nomor 56 Prp 1960) Terhadap Pelaksanaan Gadai Tanah Dalam Hukum Adat Minangkabau Di Nagari Lurah Ampalu oleh Suhardi, Program Pasca Sarjana Universitas Sumatera Utara tahun 2004. Penelitian ini membahas permasalahan mengenai pelaksanaan jual gadau tanah pertanian di Nagari Lurah Ampalu pasca berlakunya Pasal 7 Undang-Undang Nmor 56 Prp

\footnotetext{
${ }^{4}$ Aliasman, Pelaksanaan Gadai Tanah Dalam Masyarakat Hukum Adat Minangkabau Di Nagari Campago Kabupaten Padang Pariaman Setelah Berlakunya Pasal 7 Undang-Undang Nomor 56 Prp ahun 1960, http://eprints.undip.ac.id/15313/1/Aliasman.pdf

${ }^{5}$ Baca ketentuan Pasal 7 Undang-Undang Nomor 56 Prp. 1960
} 
1960. Artinya, penelitian mengenai jual tanah/adol sende di Dusun Pentong Kelurahan Selorejo Kecamatan Pundhong Kabupaten Bantul belum pernah dilakukan.

\section{B. RUMUSAN PERMASALAHAN}

Berdasarkan uraian latar belakang tersebut, melalui penelitian ini penulis ingin mengetahui beberapa hal berkaitan dengan :

1. Bagaimanakah pelaksanaan transaksi jual gadai (adol sende) oleh masyarakat Dusun Pentong, Kelurahan Selorejo, Kecamatan Pundhong, Kabupaten Bantul dalam kaitannya dengan pemberlakuan Pasal 7 Undang-Undang Nomor 56 Prp 1960?

2. Kendala-kendala apakah yang dihadapi oleh masyarakat Dusun Pentong, Kelurahan Selorejo, Kecamatan Pundhong, Kabupaten Bantul dalam melaksanakan ketentuan Pasal 7 Undang-Undang Nomor 56 Prp 1960 dalam pelaksanaan transaksi jual gadai (adol sende).

\section{METODE PENELITIAN}

Penelitian yang dilakukan merupakan penelitian hukum sosiologis/empiris. ${ }^{6}$ Penelitian hukum sosiologis/empiris adalah suatu penelitian hukum yang dilakukan dengan mengkaji peraturan perundang-undangan dan pelaksanaannya di dalam kehidupan masyarakat. Melalui penelitian ini, peneliti hendak mengkaji mengenai pelaksanaan transaksi jual gadai (adol sende) yang terjadi dalam kehidupan masyarakat. Ada pun yang dimaksud dengan masyarakat dalam penelitian ini secara spesifik menunjuk pada masyarakat yang bertempat tinggal di lokasi penelitian. Dalam penelitian ini peneliti memilih Kabupaten Bantul sebagai lokasi penelitian. Pemilihan Dusun Pentung, Kelurahan Selorejo, Kecamatan Pundong yang berada dalam yurisdiksi Kabupaten Bantul ini didasarkan pada beberapa alasan sebagai berikut:

1. Peneliti telah melakukan pra penelitian melalui wawancara singkat dengan salah seorang anggota masyarakat yang berasal dari lokasi penelitian tersebut

2. Masyarakat yang bertempat tinggal di lokasi penelitian masih melaksanakan berbagai ketentuan hukum adat dalam kehidupan sehari-hari terutama berkaitan dengan perjanjian

3. Transaksi jual gadai tanah (adol sende) merupakan salah satu transaksi yang masih sering dilakukan oleh warga masyarakat di lokasi penelitian sebagaimana dimaksud

Responden dalam penelitian ini adalah dua (2) orang warga Dusun Petung, Kelurahan Seloharjo, Kecamatan Pundhong, Provinsi Daerah Istimewa Yogyakarta atas nama Bapak Daliman (beserta Istri) dan Bapak Narti, serta Bapak Mintoredjo dan Bapak Bambang. Selain itu ada Bapak Suratman (Kepala Dukuh) setempat yang bertindak sebagai saksi dalam perjanjian yang dilakukan oleh para pihak. Adapun narasumber dalam penelitian ini adalah Bapak Suratman selaku Kepala Dukuh, Kecamatan Pundhong, Kabupaten Bantul, Provinsi Daerah Istimewa Yogyakarta dan Bapak Sunarto selaku mantan Lurah Kukup, Gunung Kidul

Teknik pengambilan sampel yang dilakukan dalam penelitian ini adalah teknik purposive sampling. ${ }^{7}$ Mengingat penelitian ini merupakan penelitian yuridis sosiologis maka pendekatan yang dilakukan adalah gabungan antara pendekatan yuridis normatif dengan pendekatan

\footnotetext{
${ }^{6}$ Soerjono Soekanto, 2006, Pengantar Penelitian Hukum, Penerbit Universitas Indonesia (UI Press), Jakarta, hal. 51

${ }^{7}$ Ibid, hal.52
} 
yuridis sosiologis. Oleh karena menggunakan dua pendekatan sekaligus, maka penelitian ini dilakukan baik dengan penelitian kepustakaan maupun dengan penelitian lapangan.

\section{PEMBAHASAN}

\section{Pelaksanaan Transaksi Jual Gadai (adol sende) oleh Masyarakat Dusun Pentung,} Kelurahan Selorejo, Kecamatan Pundhong, Kabupaten Bantul

Sebagaimana telah dikemukakan oleh peneliti pada bagian sebelumnya bahwa adol sende atau jual gadai tanah merupakan salah satu transaksi yang masih banyak dilaksanakan oleh masyarakat Dusun Pentung. Hal ini sebagaimana dituturkan oleh beberapa warga setempat. Dua di antara transaksi adol sende yang terdapat dalam masyarakat dusun ini adalah adol sende yang dilakukan antara Bapak Daliman dengan Bapak Narti serta adol sende yang dilakukan oleh Bapak Mintoredjo dengan Bapak Bambang. ${ }^{8}$

Transaksi adol sende antara Bapak Daliman dengan Bapak Narti terjadi pada bulan Februari tahun 2002. Bapak Daliman yang pada saat itu terdseak oleh kebutuhan ekonomi untuk membiayai kelahiran anak ke duanya (Adha Febrianto ) kemudian menjual tanahnya kepada Bapak Narti secara adol sende. Terhadap tanah seluas $600 \mathrm{~m}^{2}$ Pak Daliman menerima penyerahan uang sejumlah Rp 2.500.000,00 (dua juta lima ratus ribu rupiah). Sebagaimana adol sende yang terjadi di antara warga masyarakat Dusun Pentung, transaksi antara Bapak Daliman dengan Bapak Narti ini juga dilakukan secara lisan dan tanpa adanya saksi.

Untuk satuan hitungan tanah, masyarakat sekitar tidak menggunakan satuan meter persegi $\left(\mathrm{m}^{2}\right)$. Masyarakat menggunakan satuan Lobangan. Apabila dikonversikan ke satuan meter persegi:

$$
\begin{gathered}
1 \text { lobangan }=10 \mathrm{~m}^{2} \\
\text { Tanah Bapak Daliman }: 600 \mathrm{~m}^{2}=6 \text { lobangan }
\end{gathered}
$$

Berdasarkan pada ketentuan hukum adat maka Bapak Narti selaku penerima gadai tidak dapat meminta kepada Bapak Daliman selaku penggadai untuk segera melakukan penebusan atas tanahnya. ${ }^{9}$ Hal demikian juga terjadi dalam transaksi adol sende di antara Bapak Daliman dengan Bapak Narti. Pada perjalanannya adol sende antara Bapak Daliman dengan Bapak Narti ini berlangsung selama kurun waktu hampir 10 tahun. Bapak Daliman barulah kemudian melakukan penebusan terhadap tanahnya pada Bulan Januari 2012. Penebusan ini barulah terjadi setelah Bapak Daliman memiliki cukup uang untuk menebus sebidang tanahnya.

Apabila dikaitkan dengan peraturan perundang-undangan mengenai gadai tanah maka transaksi adol sende yang terjadi di antara Bapak Daliman dengan Bapak Narti sebagaimana tersebut di atas bertentangan dengan Pasal 7 Undang-Undang Nomor 56 Prp Tahun 1960. Pasal 7 Undang-Undang Nomor 56 Prp Tahun 1960 menyatakan bahwa 'barangsiapa menguasai tanah pertanian dengan hak gadai sejak berlakuknya peraturan ini

\footnotetext{
${ }^{8}$ Hasil wawancara dengan Bapak Daliman d an Bapak Mintoredjo, warga Dusun Pentunh, tanggal 05 Mei 2012

${ }^{9}$ Ukilah Suprihatin, opcit.
} 
(yaitu 1 Januari 1961) sudah berlangsung 7 (tujuh) tahun atau lebih, wajib mengembalikan tanah itu kepada pemilik dalam waktu satu bulan setelah tanaman yang ada selesai dipanen dengan tidak ada hak untuk menuntut pembayaran uang tebusan dan barang siapa melanggar maka dapat dihukum dengan hukuman kurungan selama-lamanya 3 (tiga) bulan /atau denda sebanyak-banyaknya Rp $10.000,00 .{ }^{10}$ Dengan demikian, pengembalian hak penguasaan atas tanah dari penerima kepada penggadai terjadi demi hukum. Berdasarkan pada kenyataan yang berlaku dalam masyarakat Dusun Petung sebagai salah satu implementasi berlakunya hukum adat sebagai the living law maka terhadap pelaksanaan adol sende yang dilakukan oleh Bapak Daliman dengan Bapak Narti ini tetap sah dengan berdasarkan pada ketentuan hukum adat mengenai adol sende meskipun transaksi ini tidak sesuai dengan ketentuan Pasal 7 Undang-Undang Nomor 56 Prp 1960.

Tujuan dikeluarkannya ketentuan gadai berdasarkan Pasal 7 Undang-Undang Nomor 56 Prp Tahun 1960 adalah untuk menghindari terjadinya penghisapan oleh manusia terhadap manusia lain, dalam praktik gadai tanah di Pulau Jawa (adol sende) terlihat sangat merugikan pihak penggadai (pemilik tanah). Karena terdesak akan kebutuhan uang, petani kemudian menggadaikan tanah miliknya yang dalam beberapa kondisi hal demikian justru mengakibatkan pihak penggadai terjerat oleh lintah darat. ${ }^{11}$ Namun demikian kekhawatiran akan terjadinya praktik penghisapan ini tidaklah terjadi dalam pelaksanaan adol sende di antara Bapak Daliman dengan Bapak Narti. Transaki adol sende ini sejak semula dilakukan oleh keduanya dengan itikad baik dan didasarkan pada rasa kekeluargaan. Selain itu, sejak adol sende yang dilakukan oleh kedua belah pihak telah berlangsung selama lebih dari dua tahun, Bapak Narti selaku penerima gadai telah beberapa kali meminta kepada Bapak Daliman selaku penggadai agar melakukan penebusan terhadap tanah objek gadainya. ${ }^{12}$ Tindakan Bapak Narti selaku penerima gadai dalam hal ini dapat dipandang sebagai suatu tindakan yang mencerminkan itikad baik ( good faith $)^{13}$ khususnya itikad baik pada masa kontraktual.

Menurut Undang-Undang Nomor 56 Prp Tahun 1960 yang dimaksud dengan gadai adalah hubungan antara seseorang dengan tanah kepunyaan orang lain yang mempunyai hutang kepadanya. Selama utang tersebut belum dibayar secara lunas maka tanah tetap berada dalam penguasaaan si pemegang hak gadai. ${ }^{14}$ Ada pun maksud daripada penguasaan tanah oleh si pemberi gadai adalah agar si pemberi gadai dapat memanfaatkan tanah dan mengambil hasil dari pemanfaat tersebut sebagai pengganti dari bunga atas pinjaman uang yang telah diberikannya kepada si penjual gadai. Intinya, kepemilikan ekonomis sepenuhnya mutlak pada si penerima gadai, dan pemberi gadai tidak berhak sedikitpun atas nilai ekonomis yang terkandung dalam objek gadai walaupun secara yuridis objek tersebut merupakan milik si pemberi gadai. Apabila hal ini dikaitkan dengan jangka

\footnotetext{
${ }^{10}$ Pasal 7 Undang-Undang Nomor 56 Prp Tahun 1960

11 Aliasman, Pelaksanaan Gadai Tanah Dalam Masyarakat Hukum Adat Minangkabau Di Nagari Campago Kabupaten Padang Pariaman Setelah Berlakunya Pasal 7 Undang-Undang Nomor 56 Prp tahun 1960, http://eprints.undip.ac.id/15313/1/Aliasman.pdf

${ }^{12}$ Hasil wawancara dengan Bapak Daliman, warga Dusun Pentung, tanggal 05 Mei 2012.

${ }^{13}$ Pada perkembangan hukum perjanjian dewasa ini, pelaksanaan prinsip itikad baik mencakup itikad baik pada masa pra kontraktual, kontraktual serta post kontraktual.

${ }^{14}$ Bagian Penjelasan Umum Undang-Undang Nomor 56 Prp. Tahun 1960 Tentang Gadai
} 
waktu adol sende yang terjadi antara Bapak Daliman dengan Bapak Narti maka dapat dikatakan bahwa hasil dari pemanfaatan tanah yang dilakukan oleh Bapak Narti selaku pemegang gadai selama jangka waktu 10 tahun lebih besar puluhan kali lipat dari jumlah uang yang diterima oleh Bapak Daliman sebesar Rp 2.500.000, 00 (dua juta lima ratus ribu rupiah). Tanah yang telah digadaikan selama sepuluh tahun, dengan rata-rata satu tahun panen 3 kali, dan sekali panen rata-rata memperoleh keuntungan sebesar Rp. 500.000 maka:

$$
\begin{aligned}
\text { 1x panen } & =\text { Rp. } 500.000 \text { (laba) } \\
\text { 30x panen } & =\text { Rp. } 15.000 .000 \\
\text { Uang adol sende } & =\text { Rp. } 2.500 .000
\end{aligned}
$$

Namun demikian, pada kenyataannya tidak terjadi sengketa atau pun permasalahan lain di antara Bapak Daliman dengan Bapak Narti selama tanah berada dalam penguasaan Bapak Narti. ${ }^{15}$ Hal ini dapa menjadi salah satu bukti yang menunjukan bahwa hukum adat sebagai the living law mampu menjadi suatu kaidah hukum yang mewujudkan ketentraman di tengah-tengah kehidupan masyarakat.

Selama masa adol sende berlangsung, ternyata tanah yang menjadi objek adol sende pada pertengahan masa di jual kembali kepada Bapak Rabi. Kalsifikasinya adalah doorverpanden atau pengalihan gadai ${ }^{16}$. Pengalihan gadaikan (doorverpanden) apabila pemegang gadai dengan persetujuan atau izin pemberi gadai menyerahkan tanah gadai kepada orang lain dengan penerima uang gadai dalam jumlah yang sama dari pemegang gadai yang baru. Dalam hal ini, maka hubungan hukum antara pemegang gadai yang lama putus dan berganti dengan pemegang gadai baru ${ }^{17}$.

Prakteknya, memang seperti itu, dimana saat terjadi pengalihan, Bapak Narti memberitahukannya kepada Bapak Daliman selaku penggadai bahwa tanah yang telah menjadi objek gadai telah digadai kembali oleh Bapak Narti kepada Bapak Rabi seharga yang sama dengan harga adol sende pertama. Sejak itu, tidak ada lagi hubungan hukum dalam hal adol sende antara Bapak Daliman dengan Bapak Narti. Tetapi ada sedikit perbedaan. Ketika proses pelunasan terjadi, Bapak Narti sebagai penerima gadai pertama juga turut hadir menyaksikan pelunasan Hutang yang dilakukan oleh Bapak Daliman kepada Bapak Rabi. Walaupun memang telah tidak ada hubungan antara Bapak Daliman dengan Bapak Narti.

Selain transaksi adol sende yang terjadi di antara Bapak Daliman dengan Bapak Narti, transaksi adol sende yang lain juga terjadi antara Bapak Mintoredjo dengan Bapak Bambang. Bapak Bambang selaku penggadai kemudian menyerahkan penguasaan atas sebidang tanahnya kepada Bapak Mintoredjo dengan nilai gadai sebesar Rp 2.500.000,00 (dua juta lima ratus ribu rupiah) $^{18}$. Tanah yang digadaikan oleh Bapak Bambang seluas 70 Lobangan atau sekitar $700 \mathrm{~m}^{2}$. Adol sende antara Bapak Bambang dengan Bapak

\footnotetext{
${ }^{15}$ Hasil wawancara dengan Bapak Daliman, warga Dusun Pentung, tanggal 05 Mei 2012.

${ }^{16}$ Hasil Wawancara dengan Bapak Daliman, warga Dusun Pentung, tanggal 05 Mei 2012

${ }^{17}$ Hilman Hadikusuma, Hukum Perjanjian Adat., hal.130

${ }^{18}$ Hasil wawancara dengan Bapak Mintoredjo, warga Dusun Pentung, tanggal 05 Mei 2012.
} 
Mintoredjo sudah berlangsung selama satu setengah $\left(1 \frac{1}{2}\right)$ tahun. Salah satu hal penting yang patut dikemukakan dalam hal ini adalah bahwa tanah sebagai objek yang digadaikan pada kenyataannya bukanlah tanah hak milik dari Bapak Bambang melainkan masih merupakan tanah hak milik dari orang tua Bapak Bambang yang bernama Bapak Nambangan. Dalam masyarakat Jawa terdapat sebuah hukum kebiasaan tanah 'pacung' yang berarti bahwa tanah milik orang tua secara de facto diserahkan penguasaannya kepada anak-anak mereka meskipun si orang tua masih hidup. Dengan demikian, tanah yang telah dipacungke tersebut nantinya akan menjadi milik si anak sesuai dengan pembagian masing-masing pada saat orang tuanya meninggal dunia.

Berkaitan dengan objek gadai, ditentukan bahwa hanya tanah hak milik yang dapat menjadi objek jual gadai. ${ }^{19}$ Selain itu, hak atas tanah sebagai objek gadai dalam hal ini berbeda dengan hak atas tanah yang dipergunakan sebagai jaminan melalui pengikatan hak tanggungan. Perbedaan ini terutama nampak dalam jual gadai hak penguasaan atas tanah beralih kepada pihak pemberi gadai sementara pada hak tanggungan penguasaan dan pemanfaatan atas tanah tetap berada peada penerima hak tanggungan (pemilik tanah). Sementara itu pelaksanaan transaksi adol sende di antara Bapak Mintoredjo dengan Bapak Bambang sebagaimana dimaksud dilakukan atas sebidang tanah sebagai objek gadai yang pada kenyataannya tanah tersebut belum menjadi hak milik dari Bapak Bambang selaku pengadai. Pelaksanaan transaksi yang berbeda dengan ketentuan hukum adat pada umumnya ini dapat dipandang sebagai salah satu kenyataan yang menunjukan keanekaragaman hukum adat sebagai the living law yang hidup di tengah-tengah masyarakat Indonesia.

Apabila dikaitkan dengan hukum perjanjian sebagaimana dikenal dalam hukum perdata maka perjanjian jual gadai merupakan transaksi atas tanah yang bersifat perbuatan hukum dua pihak, dengan mana pihak yang satu menyerahkan kebendaan untuk dikuasai pihak lain dengan menerima pembayaran tunai, akan tetapi si pemilik kebendaan tetap memiliki hak untuk menebus kembali di kemudian hari. ${ }^{20}$ Sementara itu yang dimaksud dengan kebendaan dalam hal ini dapat meliputi hak kebendaan atas tanah saja, rumah saja ata hak kebendaan atas tanaman yang berada di atas tanah. Hal demikian dapat dipahami mengingat konsep hak milik dalam hukum adat menganut asas pemisahan horizontal. ${ }^{21}$

Perjanjian jual gadai ini terjadi karena adanya kesepakatan di antara kedua belah pihak yaitu pihaks pemberi gadai dan pihak penerima gadai yang dalam hal initerdapat suatu perjanjian bahwa yang diserahkan bukanlah hak milik atas objek gadai akan tetapi hak atas penguasaan dan pemanfaatannya sementara hak milik masih berada pada si penerima gadai. $^{22}$ Dengan demikian, berdasarkan sifatnya maka jual gadai ini merupakan suatu perjanjian konsensual.

Mengenai keanekaragaman atas pelaksanaan transaksi adol sende ini juga dijumpai dalam praktek masyarakat Kukup Gunung Kidul. Di wilayah Kukup Gunung Kidul, transaksi adol sende ini banyak dilakukan dengan menjadikan tanah bengkok atau tanah

\footnotetext{
${ }^{19}$ Iman Sudiyat, 1981, Hukum Adat; Sketsa Hukum Adat, Liberty, Yogyakarta, hal. 28

${ }^{20}$ opcit

${ }^{21}$ Asas pemisahan horizontal menyatakan bahwa kepemilikan hak atas tanah tidak secara serta merta meliputi kepemilikan atas benda yang berada di atasnya (rumah/tanaman/benda lainnya).

22 opcit
} 
pelungguh $^{23}$ sebagai objek jual gadainya. Tanah bengkok merupakan tanah milik pemerintah Desa yang penguasaan dan pemanfaatannya diserahkan kepada para aparat desa. Aparat desa yang memiliki tanah bengkok ini dapat melakukan pemanfaatan atas tanah selama perode jabatannya. Penguasaan atas tanah kemudian akan dikembalikan pada Pemerintah desa setelah masa jabatan aparat desa berakhir dan untuk selanjutnya tanah tersebut akan diserahkan kepada perangkat desa yang baru.

Uniknya, di masayarakat setempat tidak menyebut sebagai adol sende sebagaimana pengistilahan yang selama ini dipakai untuk sistem tersebut di perkuliahan. Masyarakat di kawasan itu menyebutnya sebagai Gadai barang balik uang balik barang.

Kemudian, praktek dari sistem adol sende di masyarakat dukuh pamong juga memakai yang namanya pewarisan apabila diantara si pemberi atau penerima gadai salah satu atau keduanya meninggal, maka diwariskan hak nya (melunasi gadai bagi di penggadai atau menikmati objek gadai bagai sipenerima gadai) kepada ahli warisnya.

Dalam hal transaksi adol sende yang demikian, para aparat pamong desa yang memiliki tanah bengkok kemudian melakukan adol sende atas tanah bengkok yang dikuasainya dengan maksud untuk mendapatkan sejumlah uang dengan jangka waktu sesuai dengan masa jabatan pamong desa yang bersangkutan selaku pihak penggadai. Praktik adol sende yan terjadi di wilayah Kukup, Gunung Kidul ini turut memberikan gambaran mengenai keanekaragaman praktik pelaksanaan adol sende yang berlangsung di Yogyakarta.

\section{Kendala - Kendala yang Dihadapi Oleh Masyarakat Dusun Pentung, Kelurahan Selorejo, Kecamatan Pundhong, Kabupaten Bantul Dalam Melaksanakan Ketentuan Pasal 7 Undang-Undang Nomor 56 Prp 1960}

Jual gadai merupakan suatu perbuatan pemindahan hak atas tanah kepada pihak lain yang dilakukan secara terang dan tunai sedemikian rupa sehingga pihak yang melakukan pemindahan hak mempunyai hak untuk menebus kembali tanah tersebut. ${ }^{24}$ Dengan demikian, pihak pengadai memiliki hak untuk melakukan penebusan atas objek gadai pada masa yang akan datang. Mengenai batas waktu dalam pelaksanaan jual gadai / adol sende hukum adat menentukan batasan minimumnya yaitu selama dua kali masa panen yang umumnya berlangsung selama dua tahun di dalam praktik.

Sebagaimana telah dikemukakan oleh peneliti bahwa adol sende sabagai salah satu jenis transaksi jual tanah ini tunduk pada dua bidang hukum sekaligus. Pertama, tunduk pada ketentuan hukum adat dan ke dua tunduk pada ketentuan peraturan perundanganundangan, Ada pun khusus mengenai jangka waktu maksimal bagi pelaksanaan jual gadai tunduk pada ketentuan Pasal 7 Undang-Undang Nomor 56 Prp 1960. Walaupun ketentuan mengenai batas waktu maksimum bagi pelaksanaan jual gadai telah ditentukan dalam undang-undang namun masih terdapat sebagian pelaksanaannya dalam masyarakat yang tidak sesuai dengan ketentuan Pasal 7 Undang-Undang Nomor 56 Prp 1960 sebagaimana

\footnotetext{
${ }_{23}^{23}$ Berdasarkan pada penuturan Bapak Narto selaku mantan Lurah pada kelurahan setempat. ${ }^{24}$ ibid
} 
menentukan bahwa terhadap transaksi jual gadai yang telah berlangsung selama 7 (tujuh) tahun atau lebih maka penguasaan terhadap tanah objek gadai wajib diserahkan dari pemegang gadai kepada si penggadai. ${ }^{25}$

Berdasarkan pada penelitian yang dilakukan oleh peneliti maka setidaknya belum dilaksanakannya ketentuan Pasal 7 Undang-Undang Nomor 56 Prp 1960 ini paling disebabkan oleh dua hal yang menjadi kendala yaitu kendala internal dan kendala eksternal. Kendala internal terutama disebabkan oleh ketidaktahuan masyarakat akan keberadaan Pasal 7 Undang-Undang Nomor 56 Prp 1960. Hal demikian dapat dipahami mengingat sangat langkanya warga dusun yang mengenyam pendidikan hingga perguruan tinggi. ${ }^{26}$ Selain itu, secara inernal masyarakat telah merasa nyaman melakukan berbagai transaksi utamanya yang berkaitan dengan tanah denan mendasarkan pada kepercayaan dan kekeluargaan hingga tak jarang transaksi ekonomi yang hanya dilakukan seara lisan.

Sementara itu kendala eksternal terutama disebabkan oleh kurangnya perhatian dari para pihak yang berkepentingan akan adanya sosialisasi terhadap ketentuan peraturan perundang-undangan khususnya dalam hal ini adalah Pasal 7 Undang-Undang Nomor 56 Prp 1960. Sosialisasi terhadap suatu peraturan perundang-undangan tidak hanya dapat dilakukan oleh pemerintah tetapi juga dapat dilakukan oleh kalangan akademisi misalnya melalui penyelenggaraan Kuliah Kerja Nyata (KKN) oleh mahasiswa dari berbagai universitas. Namun demikian, setidaknya selama empat (4) tahun terakhir belum ada program KKN yang berlangsung di Dusun Pentung. ${ }^{27}$ Hal ini tidak terlepas dari masih adanya rasa takut atas gempa bumi yang turut meluluhlantahkan wilayah Dusun Pentung pada tahun 2006 silam.

\section{E. PENUTUP}

\section{Kesimpulan}

Pelaksanaan transaksi jual gadai (adol sende) oleh masyarakat Dusun Pentong, Kelurahan Selorejo, Kecamatan Pundhong, Kabupaten Bantul dalam kaitannya dengan pemberlakuan Pasal 7 Undang-Undang Nomor 56 Prp 1960 ternyata tidak terjadi keharmonisan. Masyarakat dusun Pentong tetap pada living law mereka, dimana pelaksanaan jual gadai tanah ini tanpa batas waktu tertentu. Pembatasan waktu pelaksanaan maksimum 7 tahun yang diatur pada Pasal 7 Undang-Undang Nomor 56 Prp 1960 tidak diketahui oleh masyarakat Dusun Pentong setempat. Saat peneliti pada akhirnya memberitahukan masyarakat dusun Pentong pada aturan ini, mereka pun tetap pada pendiriannya untuk tidak membatasi masa transaksi jual gadai tanah. Praktek pelaksanaan transaksi jual gadai pun berlangsung amat sederhana. Tawar menawar harga terjadi diawal sebelum perjanjian disepakati, kemudian ketika tercapai kata sepakat, perjanjian dibuat. Bentuk penjanjian dari jual gadai ini adalah perjanjian lisan dengan tanpa saksi.

Kendala-kendala yang dihadapi oleh masyarakat Dusun Pentong, Kelurahan Selorejo, Kecamatan Pundhong, Kabupaten Bantul dalam melaksanakan ketentuan Pasal 7 UndangUndang Nomor 56 Prp 1960 dalam pelaksanaan transaksi jual gadai (adol sende) adalah

\footnotetext{
${ }^{25}$ Pasal 7 Undang-Undang Nomor 56 Prp 1960.

${ }^{26}$ Hasil wawancara dengan Bapak Suratman selaku Kepala Dukuh Pentung, tanggal 05 Mei 2012.

${ }^{27}$ Hasil wawancara dengan Bapak Daliman, warga Dusun Pethung, tanggal 05 Mei 2012
} 
bahwa mereka tidak mengetahui sama sekali tentang aturan batas waktu pelaksanaan jual gadai ini. Saat diberikan edukasipun, walaupun sebenarnya mereka sangat menyayangkan bahwa sebenarnya (untuk kasus Bapak Daliman) seharusnya dia tidak perlu membayar satu rupiahpun akan tanahnya yang telah di gadaikannya kepada si penerima gadai, namun pada akhirnya mereka lebih memilih untuk tetap memakai kebiasaan yang telah mendarah daging, karena dua alasan utama, internal dan eksternal:

a. Ketidaktahuan masyarakat akan keberadaan Pasal 7 Undang-Undang Nomor 56 Prp 1960. Hal demikian dapat dipahami mengingat sangat langkanya warga dusun yang mengenyam pendidikan hingga perguruan tinggi.

b. Masyarakat telah merasa nyaman melakukan berbagai transaksi utamanya yang berkaitan dengan tanah denan mendasarkan pada kepercayaan dan kekeluargaan hingga tak jarang transaksi ekonomi yang hanya dilakukan seara lisan. Masyarakat menganggap bahwa si penerima gadai adalah penolong bagi si pemberi gadai, karena si penerima gadai telah membantu memberikan pinjaman uang kepada di pemberi gadai. Bagaimanapun juga masyarakat dusun pentong sangat menjaga tali silaturrahmi. Prinsipnya, lebih baik mereka kehilangan uang daripada kehilangan saudara

Sementara itu kendala eksternal terutama disebabkan oleh kurangnya perhatian dari para pihak yang berkepentingan akan adanya sosialisasi terhadap ketentuan peraturan perundang-undangan khususnya dalam hal ini adalah Pasal 7 Undang-Undang Nomor 56 Prp 1960. Apa yang menjadi kekhawatiran pembentuk Undang-undang sehingga mengeluarkan produk hukum berupa Pasal 7 Undang-Undang Nomor 56 Prp 1960 tentang pemerasan dan berpindahnya hak milik karena tanah gadai yang terlalu lama dikuasai oleh si penerima gadai, belum pernah terjadi di dusun pentong ini. Selama apapun tanah gadai berada ditangan si penerima gadai, kejadian berpindahnya kepemilikan secara diam-diam dan melawan hukum tidak pernah terjadi.

\section{Saran}

Melihat kendala kendala hukum dalam pelaksanaan adol sende, maka hal ini salah satu penyebabnya adalah kurangnya perhatian dari para pihak yang berkepentingan akan adanya sosialisasi terhadap ketentuan peraturan perundang-undangan khususnya dalam hal ini adalah Pasal 7 Undang-Undang Nomor 56 Prp 1960. Sosialisasi terhadap suatu peraturan perundang-undangan tidak hanya dapat dilakukan oleh pemerintah tetapi juga dapat dilakukan oleh kalangan akademisi misalnya melalui penyelenggaraan Kuliah Kerja Nyata (KKN) oleh mahasiswa dari berbagai universitas. Namun demikian, selama empat (4) tahun terakhir belum ada program KKN yang berlangsung di Dusun Pentung. ${ }^{28}$ Hal ini tidak terlepas dari masih adanya rasa takut atas gempa bumi yang turut meluluhlantahkan wilayah Dusun Pentung pada tahun 2006 silam.

\section{DAFTAR PUSTAKA}

\section{Buku}

Al-Qur'an dan Al-Hadits

${ }^{28}$ Hasil wawancara dengan Bapak Daliman, warga Dusun Pethung, tanggal 05 Mei 2012 
Abdoel. Djamali, 2005, Pengantar Hukum Indonesia, Raja Grafindo Persada; Jakarta

Hilman. Hadikusuman, 1994, Hukum Perjanjian Adat, Citra Aditya Bakti: Bandung ------------, 2001, Hukum Perekonomian Adat Indonesia, Citra Aditya Bakti: Bandung

Iman. Sudiyat, 1985, Asas-asas Hukum Adat Bekal Pengantar, Liberti Yogyakarta; Yogyakarta

Soekanto, 1955, Meninjau Hukum Adat Indonesia, Jakarta, cet. III.

Soerjono Soekanto, 2006, Pengantar Penelitian Hukum, Penerbit Universitas Indonesia (UI Press), Jakarta

Sulastriyono, Hukum Jaminan dalam Aspek Islam. Slide Power Point untuk bahan ajar Hukum Jaminan, tanggal 27 April 2012

\section{Internet}

Aliasman, Pelaksanaan Gadai Tanah Dalam Masyarakat Hukum Adat Minangkabau Di Nagari Campago Kabupaten Padang Pariaman Setelah Berlakunya Pasal 7 UndangUndang Nomor 56 Prp ahun 1960, http://eprints.undip.ac.id/15313/1/Aliasman.pdf

Ukilah Supriyatin, Jaminan Kepastian Hukum Terhadap Perjanjian Gadai Tanah Menurut Hukum Adat, http://jurnal.pdii.lipi.go.id/admin/jurnal/13101118_2086-8111.pdf

\section{Peraturan Perundang-undangan}

Undang Undang Dasar Negara Republik Indonesia Tahun 1945

Undang-Undang Nomor 5 Tahun 1960 Tentang Ketentuan Pokok Agraria

Peraturan Pemerintah Pengganti Undang-Undang Nomor 56 Tahun 1960

Yurisprudensi MA 01 April 1975 No. 1272 K/Sip/1975 dan 17 Mei 1975 No. 30 K/Sip /1975

Putusan Mahkamah Agung nomer 574/K/Pdt/2010 